\title{
Activity of Chlorine Dioxide in a Solution of Ions and pH Against Thielaviopsis basicola and Fusarium oxysporum
}

\author{
W. E. Copes, Small Fruit Research Station, USDA-ARS, Poplarville, MS 39470; and G. A. Chastaganer and \\ R. L. Hummel, Puyallup Research and Extension Center, Washington State University, Puyallup 98371
}

\begin{abstract}
Copes, W. E., Chastaganer, G. A., and Hummel, R. L. 2004. Activity of chlorine dioxide in a solution of ions and $\mathrm{pH}$ against Thielaviopsis basicola and Fusarium oxysporum. Plant Dis. $88: 188-194$

Chlorine dioxide $\left(\mathrm{ClO}_{2}\right)$ is a disinfestant used to control pathogens in water. To determine if interactions between inorganic ions and $\mathrm{pH}$ levels effect $\mathrm{ClO}_{2}$ activity in vitro, concentrations of $\mathrm{ClO}_{2}(0,1,3,5,7,9,22,24,46,58$, and $70 \mathrm{mg} / \mathrm{liter})$ were mixed for $10 \mathrm{~min}$ in solutions containing a nitrogen and hard water solution with equal concentrations of ammonium, nitrate, and synthetic hard water ( 0 and $100 \mathrm{mg} /$ liter) and a divalent metal ion solution with equal concentrations of copper, iron, manganese, and zinc $(0,1,3$, and $5 \mathrm{mg} / \mathrm{liter})$ at $\mathrm{pH} 5$ and 8 . Macro- and microconidia of Fusarium oxysporum f. sp. narcissi or conidia and aleuriospores of Thielaviopsis basicola were injected into each suspension for $30 \mathrm{~s}$, captured on filter paper disks that were flushed with water, and plated on 50\% potato dextrose agar. Spore germination was quantified after 1 day. $\mathrm{ClO}_{2}$ activity had a similar effect on both fungal species and all types of propagules with interactions among the divalent metal ion solution, nitrogen and hard water solution, and $\mathrm{pH}$ treatments. A higher concentration of $\mathrm{ClO}_{2}$ was required at $\mathrm{pH} 8$ than at $\mathrm{pH} 5$ to achieve a lethal dose resulting in $50 \%$ mortality of spores $\left(\mathrm{LD}_{50}\right)$. The addition of the divalent metal ion solution required an increase in $\mathrm{ClO}_{2}$ concentration to maintain a $\mathrm{LD}_{50}$. When combined with the nitrogen and hard water solution, the divalent metal ion solution placed a higher demand on $\mathrm{ClO}_{2}$ at $\mathrm{pH} 5$ and a lower demand on $\mathrm{ClO}_{2}$ at $\mathrm{pH}$ 8, thus requiring an increase and decrease in a $\mathrm{ClO}_{2}$ concentration, respectively, to achieve a $\mathrm{LD}_{50}$. Chlorine dioxide doses resulting in $50 \%$ mortality ranged from 0.5 to $7.0 \mathrm{mg} /$ liter for conidia of $F$. oxysporum, 0.5 to 11.9 $\mathrm{mg} / \mathrm{liter}$ for conidia of T. basicola, and 15.0 to $45.5 \mathrm{mg} / \mathrm{liter}$ for aleuriospores of T. basicola.
\end{abstract}

Additional keywords: black root rot, Chalara, Fusarium basal rot

Chlorine dioxide $\left(\mathrm{ClO}_{2}\right)$ is a disinfestant approved for treatment of public and private drinking water and of poultry effluent at processing facilities, as well as for meat processing (fish, red meat, and poultry) facilities, postharvest handling of fruits and vegetables, and in some states, for postharvest treatment of potatoes in storage (22, EPA Reg. No. 5382-43-43553). Forms of chlorine other than $\mathrm{ClO}_{2}$ (sodium and calcium hypochlorite and chlorine gas) are commonly used by ornamental plant producers. However, $\mathrm{ClO}_{2}$ is chemically different from other chlorine disinfestants $(1,7,8,16,17,21)$. Chlorine dioxide has an oxidative potential 2.5 times greater than hypochlorites and second only to ozone $(1,8)$. Hypochlorites and chlorine gas hydrolyze rapidly in water to form hypochlorous acid, while $\mathrm{ClO}_{2}$ does not hydrolyze appreciably in water but remains in solution as a gas. Chlorine dioxide has a

Corresponding author: W. Copes

E-mail: wcopes@ars.usda.gov

Accepted for publication 21 September 2003.

Publication no. D-2003-1119-02R

(C) 2004 The American Phytopathological Society solubility five times that of chlorine gas and forms a monomeric structure that is more stable in water suspension than other chlorine products (17). Hypochlorites and chlorine gas react by oxidation and electrophilic substitution, while chlorine dioxide reacts only by oxidation, generally as an electron acceptor. As a result, hydrogen atoms present in activated organic structures are not substituted by chlorine dioxide. Therefore, chlorinated organic byproducts are less commonly produced with $\mathrm{ClO}_{2}$ treatments than when treating with other forms of chlorines, and low to negligible levels of chlorophenols, halo acetic acids, and trihalomethanes are formed. The latter is a primary reason for the increased use of $\mathrm{ClO}_{2}$ for treating drinking water.

One disadvantage of $\mathrm{ClO}_{2}$ over other chlorine products is the cost of a computermonitored system to generate $\mathrm{ClO}_{2}$ on-site. Chlorine dioxide can be generated using any of a number of methods, and delivery systems vary with application from treatment of drinking water to industrial wastes. Three delivery systems are currently commercially available for agricultural uses $(22,24)$.

Chlorine dioxide exhibits biocidal activity against a range of organisms, including algae, animal planktons, bacteria, fungi, and viruses $(4,14,15,18,19,24)$. Researchers have demonstrated that high biocidal activity was obtained from $\mathrm{ClO}_{2}$ with concentrations and duration of exposure that ranged from 1 to $9 \mathrm{mg} / \mathrm{liter}$ and 1 to 20 min, respectively. For example, a high reduction in viable propagules resulted when conidia or sporangiospores of Botrytis cinerea, Penicillium expansum, Mucor piriformis, and Cryptosporiopsis perennans were exposed to $\mathrm{ClO}_{2}$ at 3 to 5 $\mathrm{mg} / \mathrm{liter}$ for $1 \mathrm{~min}$, and when Phytophthora cinnamomi, Fusarium oxysporum, Colletotrichum capsici, Pythium ultimum, and Alternaria zinniae were exposed to $\mathrm{ClO}_{2}$ at $3 \mathrm{mg} / \mathrm{liter}$ for $8 \mathrm{~min}(18,24)$. These papers demonstrated that concentration of $\mathrm{ClO}_{2}$ varies with time, with an equal mortality of propagules obtained at lower concentrations of $\mathrm{ClO}_{2}$ by lengthening the duration of exposure. The upper rate of $9 \mathrm{mg} \mathrm{ClO}_{2}$ per liter is higher than rates commonly used to treat drinking water or in fruit and vegetable dump tanks, where rates of 2 to $5 \mathrm{mg} /$ liter are commonly used.

The effectiveness of disinfestants also depends on the properties of water $(\mathrm{pH}$, water hardness, suspended solids, inorganic and organic molecules, turbidity, and temperature) and the treatment process, which affect the distribution of disinfestant in the body of water and the duration that molecules with biocidal activity are in contact with target organisms $(1,7,8,10,17)$. All disinfestants, including $\mathrm{ClO}_{2}$, react rapidly with various molecules, elements, particles, and organisms in suspension. These reactions create a demand (termed demand load) that lowers the concentration available to contact, be absorbed by, and inactivate micro-organisms. Chlorine dioxide is oxidized by $\mathrm{Fe}^{2+}$ and $\mathrm{Mn}^{2+}$ ions to precipitate ferric hydroxide and manganese oxide, respectively (7). Chlorine dioxide does not react with ammonia, bromides, nitrate, hard water, and zinc $(5,7)$. Although $\mathrm{ClO}_{2}$ is primarily used as an oxidizing agent, it is both oxidized and reduced under alkaline conditions, a process termed disproportionation, and the rate is rapidly accelerated at $\mathrm{pH} \geq 10(12,27)$.

Water hardness used to be measured by the capacity of water to precipitate soap (5). Current numerical values of water hardness are primarily the sum of carbonate and bicarbonate alkalinity, collectively termed "carbonate hardness" (5). Carbonate hardness is chiefly due to the presence of calcium and magnesium ions. Addi- 
tional hardness has been attributed to complex polyvalent cations associated with organic constituents, and is termed "noncarbonate hardness". Noncarbonate hardness can be difficult to define and is thought to be of minimal influence in water systems. In this research project, synthetic hard water will be strictly due to carbonate hardness. No references were found by the authors that noted an interaction between water hardness and $\mathrm{ClO}_{2}$ activity. Water hardness of $400 \mathrm{mg} / \mathrm{liter}$ did not inhibit activity from $5 \mathrm{mg} / \mathrm{liter}$ available chorine derived from sodium hypochlorite (26).

A small survey of public leaflets distributed by city water authorities (Atlanta, GA; Bakersfield, CA; Bellingham, WA; Boston, MA; Columbus, OH; Everett, WA; Hattiesburg, MS; Mt. Vernon, WA; Olympia, WA; Puyallup, WA; Spokane, WA; Tacoma, WA; and Wenatchee, WA) about public drinking water showed that $\mathrm{pH}$ ranged from 5.6 to 10.1 , water hardness ranged from 1 to $222 \mathrm{mg} / \mathrm{liter}$ carbonate hardness, nitrates ranged from 0.001 to $18.000 \mathrm{mg} / \mathrm{liter}$, and minerals such as iron and manganese ranged form 0.0001 to $0.5000 \mathrm{mg} / \mathrm{liter}$. These properties may vary to a greater degree in unregulated water sources, and elemental levels from nutrient leachates may be higher in some catchment ponds (7).

Chlorine dioxide can be used to disinfest irrigation water used in nursery and greenhouse ornamental plant production systems. Since cost of a chemical is a consideration in choosing a disinfestation system, and $\mathrm{ClO}_{2}$ systems also require an initial investment of a computerized mixing and injection system, demand load responses that affect usage rates must be understood. Our objective was to determine the relative degree of interaction between inorganic ions and $\mathrm{pH}$ that affect the biocidal activity of $\mathrm{ClO}_{2}$, measured as a function of concentration with a set exposure period (30 s) against several types of propagules from two fungi. Micro- and macroconidia of Fusarium oxysporum f. sp. narcissi (Cooke \& Massee) and conidia of Thielaviopsis basicola (Berk. \& Broome) Ferraris (syn. Chalara elegans Nag Raj \& Kendrick) were selected to provide a diversity of hyaline spore types. The thick-walled, melanized aleuriospores of $T$. basicola were used as a propagule type that potentially had low sensitivity to $\mathrm{ClO}_{2}$. The information generated from this research indicates whether a narrow or wide range in rate of $\mathrm{ClO}_{2}$ is needed for efficacy against different fungal propagules as a result of the interactions of water properties (e.g., $\mathrm{pH}$ and water hardness) that vary with the source (e.g., ponds, wells, municipal water, and recirculating systems), in combination with the presence of nutrient leachates that collect in catchment ponds and ebb-and-flow systems.

\section{MATERIALS AND METHODS}

Inoculum. Chlamydospores of $F$. oxysporum f. sp. narcissi (isolate $\mathrm{KMH}-3$ obtained from a 'Mt. Hood' daffodil bulb in 1993) were produced and stored in talc as described by Price (23). The talcinoculum mixture was stored in plastic jugs at room temperature until inoculum was needed to start a culture. Cultures were grown on potato dextrose agar (PDA) for 10 to 14 days under cool fluorescent lights. Conidial suspensions were made by flooding plates with $10 \mathrm{ml}$ of sterile, deionized water, scraping the surface with a sterile rubber policeman, and swirling and filtering the suspension through four layers of sterile cheesecloth. The plate was flooded a second time with $5 \mathrm{ml}$ of water and the process repeated. Spores were enumerated using a hemacytometer and adjusted to obtain $1.0 \times 10^{6}$ conidia per $\mathrm{ml}$ in a 20-ml suspension. The amount of spore suspension added to $20 \mathrm{ml}$ of a treatment solution averaged $0.28 \mathrm{ml}$. Spore suspensions were made daily as needed. Inoculum intended for use $2.5 \mathrm{~h}$ after preparation was subdivided into separate sterile beakers, covered with sterile aluminum foil, stored at $5^{\circ} \mathrm{C}$, and returned to room temperature $15 \mathrm{~min}$ before use.

T. basicola (isolated from roots of Fuchsia $\times$ hybrida) was grown on V8 agar for 14 to 18 days to obtain predominately conidia, and on Difco PDA (Benton Dickson and Co., Sparkes, MD) with $2 \%$ yeast extract for 18 to 24 days to obtain aleuriospores. Spore suspensions that consisted predominately of conidia were prepared as described for $F$. oxysporum f. sp. narcissi. For suspensions that contained predominately aleuriospores, the agar was flushed with a gentle stream of sterile, deionized water using a wash bottle to remove most of the conidia, then inoculum preparation procedures were followed as described for F. oxysporum f. sp. narcissi.

pH, nitrogen, water hardness, and micronutrients. Certified buffer solutions (Fisher Scientific, Pittsburgh, PA) were used for $\mathrm{pH} 5$ and 8. The ammonium, nitrate, copper, iron, manganese, and zinc solutions were made with ammonium sulfate $\left(\left(\mathrm{NH}_{4}\right) \mathrm{SO}_{4}\right)$, potassium nitrate $\left(\mathrm{KNO}_{3}\right)$, copper sulfate $\left(\mathrm{CuSO}_{4} \cdot 7 \mathrm{H}_{2} \mathrm{O}\right)$, manganese sulfate $\left(\mathrm{MnSO}_{4} \cdot \mathrm{H}_{2} \mathrm{O}\right)$, and zinc sulfate $\left(\mathrm{ZnSO}_{4} \cdot 7 \mathrm{H}_{2} \mathrm{O}\right)$. Chelated iron was prepared by: dissolving iron sulfate $(84 \mathrm{~g}$ $\mathrm{FeSO}_{4} \cdot 7 \mathrm{H}_{2} \mathrm{O}$ ) in 1 liter of deionized water; dissolving ethylenediamine tetraacetic acid (84.6 g EDTA-disodium salt) in a second liter of deionized water; adding sodium hydroxide $(10 \mathrm{~g} \mathrm{NaOH})$ to the EDTA solution; mixing the two solutions; adjusting total volume of the solution to 3 liters with deionized water; and holding it in the dark for $24 \mathrm{~h}$ with air gently bubbling through the solution. The final solution was a clear, tan-brown color. Precipitate formed 2 days after making the solution. Clarity of the solution was returned by adding $5 \mathrm{ml}$ of hydrochloric acid (20\% vol/vol). Synthetic hard water (sHW) was a mixture of two solutions: (i) $\mathrm{MgCl}_{2}$ and $\mathrm{CaCl}_{2}$ and (ii) $\mathrm{NaHCO}_{3}$ (11). The sHW mixture deviated from the recipe of Helrich (11) because the $\mathrm{pH}$ was specified to be 7.6 to 8.0 , but $\mathrm{pH}$ was a treatment in these experiments.

Each treatment evaluated in the experiment was a combination of up to eight factors: $\mathrm{pH}, \mathrm{sHW}, \mathrm{NH}_{4}, \mathrm{NO}_{3}, \mathrm{Mn}, \mathrm{Cu}, \mathrm{Zn}$, and/or Fe. A single replication of all factors at all levels of the full factorial design could not be run in a single day, so results from single-factor trials were used as the basis to combine $\mathrm{Cu}, \mathrm{Fe}, \mathrm{Mn}$, and $\mathrm{Zn}$ as a single factor (divalent metal ion solution) and $\mathrm{NH}_{4}, \mathrm{NO}_{3}$, and sHW as a single factor (nitrogen and hard water solution) (6). $\mathrm{Cu}$, $\mathrm{Fe}, \mathrm{Mn}$, and $\mathrm{Zn}$ were combined as a single factor, because Mn was determined to be highly influential on the biocidal activity of $\mathrm{ClO}_{2}, \mathrm{Fe}$ to have a small but negligible effect, and $\mathrm{Cu}$ and $\mathrm{Zn}$ to have no effect on $\mathrm{ClO}_{2}$ activity when each was tested as a single factor at $5 \mathrm{mg} / \mathrm{liter}$ of the metal ion. The concentrations of $\mathrm{Cu}, \mathrm{Fe}, \mathrm{Mn}$, and $\mathrm{Zn}$ in these solutions were equal. Ammonium, $\mathrm{NO}_{3}$, and sHW were combined as a single factor, because each had no effect on $\mathrm{ClO}_{2}$ activity when tested as a single factor (6). A nitrogen and hard water solution with $100 \mathrm{mg} /$ liter contained $200 \mathrm{mg} \mathrm{N}$ per liter with $100 \mathrm{mg} \mathrm{N}$ per liter from $\left(\mathrm{NH}_{4}\right)_{2} \mathrm{SO}_{4}$, $100 \mathrm{mg} \mathrm{N}$ per liter from $\mathrm{KNO}_{3}$ (granular), and $100 \mathrm{mg} /$ liter of $\mathrm{CaCO}_{3}$ equivalent. While effects from individual nutrients were confounded by combining these factors in one solution, this allowed for a complex solution that contained all factors while limiting the number of treatments. Each treatment combination was made as a separate solution and pipetted into culture tubes with the appropriate certified $\mathrm{pH}$ buffer solution as the base liquid.

Chlorine dioxide. $\mathrm{A} \mathrm{ClO}_{2}$ stock solution was manufactured daily as needed by mixing IVR-SAN 15 (15\% sodium chlorite and $4.5 \%$ sodium chloride) and Activator$\mathrm{H}$ (14.4\% wt/wt hydrochloric acid) $\left(\mathrm{CH}_{2} \mathrm{O}\right.$ International, Inc., Olympia, WA). The chemical reaction:

$5 \mathrm{NaClO}_{2}+4 \mathrm{HCl} \rightarrow 4 \mathrm{ClO}_{2}+5 \mathrm{NaCl}+2 \mathrm{H}_{2} \mathrm{O}$

results in the production of $\mathrm{ClO}_{2}$ with lower chlorate levels than other methods of production (1). An iodometric titration method was used to determine $\mathrm{ClO}_{2}$ concentration of the stock solution, which ranged from 26,000 to $32,000 \mathrm{mg} / \mathrm{liter}(9)$. Chlorine dioxide stock solution was produced in an amber glass bottle, capped with a Parafilm-covered rubber stopper at all times, and stored at $5^{\circ} \mathrm{C}$ to inhibit photolytic degradation and volatilization. If two replications were to be done in a day, the stock solution was divided equally and stored at $5^{\circ} \mathrm{C}$. During each experiment, the $\mathrm{ClO}_{2}$ stock solution being used was partially submersed in iced water and quickly recapped after withdrawal of each aliquot. 
Suspension tests. Test factors and the levels of each test factor evaluated for efficacy against micro- and macroconidia of $F$. oxysporum f. sp. narcissi and conidia of $T$. basicola included: $\mathrm{ClO}_{2}$ at $0,1,3,5$, 7 , and $9 \mathrm{mg} / \mathrm{liter}$; the divalent metal ion solution at $0,1,3$, and $5 \mathrm{mg} / \mathrm{liter}$; the nitrogen and hard water solution at 0 and $100 \mathrm{mg} / \mathrm{liter}$; and pH 5 and 8. Test factors and their levels evaluated for efficacy against aleuriospores of $T$. basicola were $\mathrm{ClO}_{2}$ at $0,22,34,46,58$, and $70 \mathrm{mg} / \mathrm{liter}$; the divalent metal ion solution at 0 and 5 $\mathrm{mg} / \mathrm{liter}$; the nitrogen and hard water solution at 0 and $100 \mathrm{mg} / \mathrm{liter}$; and $\mathrm{pH} 5$ and 8. All experiments were repeated once.

Twenty milliliters of each solution was pipetted into sterile, borosilicate, plain end, culture tubes $(16 \times 100 \mathrm{~mm})$ capped with Sav-It Tube (Fisher Scientific) flexible red closures $(16 \mathrm{~mm})$. The required concentrations of $\mathrm{ClO}_{2}$ (0 to $\left.70 \mathrm{mg} / \mathrm{liter}\right)$ were produced by adding the appropriate volume of stock solution to $20 \mathrm{ml}$ of the treatment solution in a culture tube. The culture tube was placed on a Labquake tube shaker $(16.5 \times 27.9 \mathrm{~cm})$ for $10 \mathrm{~min}$. Conidial suspension was added with a 1-ml disposable plastic syringe, using a 23-gauge hypodermic needle, by piercing the Sav-It Tube closure on top of the culture tube. The culture tube was placed back on the shaker for $30 \mathrm{~s}$. Contents of the culture tube were poured through a sterile 12.5cm-diameter P-2 filter paper (Fisher Scientific) pressed into a Coors porcelain Büchner funnel with a fixed perforated plate (100 mm diameter), which was connected to a Welch vacuum pump. When the solution had been drawn completely down through the filter paper, $50 \mathrm{ml}$ of sterile, deionized water was added to flush $\mathrm{ClO}_{2}$ from the filter. The filter paper was removed and cut with scissors to leave a 5.08 $\mathrm{cm}^{2}$ piece that was inverted onto the surface of half-strength PDA (1/2-PDA) in a 15 $\times 100 \mathrm{~mm}$ plastic petri plate. Between treatments, the inner cup of the Büchner funnel was rinsed with a $10 \%$ bleach solution (5.25\% sodium hypochlorite); counter surfaces were sprayed with $95 \%$ ethanol and wiped off; and tweezers and scissors were dipped in $95 \%$ ethanol and flamed.

Petri plates were stacked two to four high in rows with each successive layer staggered by half a plate. The following day, the filter paper was removed, and $>100$ spores were checked for germination within the middle of the area in which the filter was placed. Plates were placed back under fluorescent lights in the same stacking pattern. On the third day after plating, spore germination was evaluated. By day 3 , germination was more difficult to evaluate in plates with significant mycelial growth.

Experimental design. A randomized complete block design with four replications, blocked by time, was used in all three experiments. Experiments with conidia of $F$. oxysporum f. sp. narcissi, co- nidia of $T$. basicola, and aleuriospores of $T$. basicola had 48, 33, and 24 treatments, respectively. A replication consisted of one culture tube containing the specific water solution $(\mathrm{pH}$, nitrogen and hard water solution, and divalent metal ion solution) and $\mathrm{ClO}_{2}$ concentration.

The number of treatment factors and levels were restricted to the number that could be run within a 2.5 -h period. The concentration of $\mathrm{ClO}_{2}$ in the stock solution did not diminish during this period but did diminish within a 4-h period. As a result, variation among treatments was partially controlled by blocking each replication within a 2.5 -h period.

Preliminary experiments were done to determine the range in concentrations of $\mathrm{ClO}_{2}$ that would result in percent ungerminated spores $>0$ and $<100$ at multiple $\mathrm{ClO}_{2}$ concentrations, for calculating a dose curve response. Because of the use of solutions with combined factors and partial treatment selection, a potential existed for unanticipated interactions; therefore all treatment factors and levels were tested at a single $\mathrm{ClO}_{2}$ level (3 mg $\mathrm{ClO}_{2}$ per liter) that was likely to result in an intermediate level of biocide activity in each experiment.

Statistical analysis. The SAS probit analysis (PROC PROBIT), a nonlinear regression that accounts for unequal variances, was used to obtain prediction values and confidence limits (CLs) (SAS Institute, Cary, $\mathrm{NC}$ ). The $\mathrm{LD}_{50}$ provides the highest precision for statistical comparisons of the commonly used dose-response design; therefore, $\mathrm{LD}_{50}$ values were compared based on confidence limits (25). Insufficient evidence existed to reject the null hypothesis of equal means $\left(\mathrm{H}_{0}: \mathrm{LD}_{50} 1\right.$ $=\mathrm{LD}_{50}$ 2) when confidence limits of $\mathrm{LD}_{50} \mathrm{~s}$ overlapped. In addition, the variance of $\mathrm{LD}_{50} \mathrm{~s}$ was compared based on slopes and associated standard errors for each treatment combination, e.g., a significantly larger slope indicates a smaller variance, which means a greater change in biocidal activity of $\mathrm{ClO}_{2}$ per unit change in concentration of $\mathrm{ClO}_{2}$ compared with a smaller slope. With a smaller slope, more units of $\mathrm{ClO}_{2}$ are required to reach a higher LD, such as the $\mathrm{LD}_{90}$, than with a larger slope (25). Slopes were compared based on a $t$ ' test (20). If the $t^{\prime}$ value, calculated by

$$
t^{\prime}=\left(\beta_{1}-\beta_{2}\right) \div\left[s^{2}\left(\beta_{1}\right)+s^{2}\left(\beta_{2}\right)\right]^{1 / 2}
$$

was less than or equal to the $t_{\alpha}$ value of

$$
t_{\alpha}=t\left[0.05 ; \eta_{1}+\eta_{2}-(2 p)\right]
$$

then insufficient evidence existed to reject the null hypothesis of equal slopes $\left(\mathrm{H}_{0}: \beta_{1}\right.$ $=\beta_{2}$ ), where $\beta_{1}$ and $\beta_{2}$ are the slopes being compared, $s^{2}\left(\beta_{1}\right)$ and $s^{2}\left(\beta_{2}\right)$ are the standard deviations of $\beta_{1}$ and $\beta_{2}$, respectively, $\eta_{1}$ and $\eta_{2}$ are the total numbers of observations used to calculate $\beta_{1}$ and $\beta_{2}$, respectively, $p$ is the number of parameters being compared, and $t$ is the critical value from a $t$ table with a significance level of 0.05 and $\eta_{1}+\eta_{2}-(2 p)$ degrees of freedom (20). $\mathrm{LD}_{90}$ values were not used in the statistical analysis but are provided in the results because they are more representative of rates of $\mathrm{ClO}_{2}$ that would be used to treat irrigation water commercially than the $\mathrm{LD}_{50}$ values.

For $F$. oxysporum f. sp. narcissi, significance between experiments and all other factors was tested by an analysis of variance procedure using PROC MIXED (SAS Institute). For both spore types of $T$. basicola, significance between experiments was tested by comparison of $\mathrm{LD}_{50}$ values, with experiments being not significantly different only if the same factors had overlapping confidence intervals of $\mathrm{LD}_{50}$ values.

Interactions between the nitrogen and hard water solution, the divalent metal ion solution, and $\mathrm{pH}$ were tested based on a regression of mortality and divalent metal ion solution dose at $3 \mathrm{mg} \mathrm{ClO}_{2}$ per liter using the divalent metal ion solution concentrations versus the concentration of $\mathrm{ClO}_{2}$ as the dependent variable. As a result, the slope was negative, but the lethal dose values were used only as a means to compare treatments. This was termed a secondary lethal dose $\left(2^{\circ} \mathrm{LD}_{50}\right)$ because mortality was a measure of the $\mathrm{LD}_{50}$ caused by 3 $\mathrm{mg} \mathrm{ClO}_{2}$ per liter after it had reacted with the divalent metal ion solution and was not due directly to the divalent metal ion solution dose.

A low $2^{\circ} \mathrm{LD}_{50}$ means the divalent metal ion solution was highly reactive with $\mathrm{ClO}_{2}$, so only a relatively small concentration of the divalent metal ion solution was required to reduce $\mathrm{ClO}_{2}$ activity. A high $2^{\circ}$ $\mathrm{LD}_{50}$ means the divalent metal ion solution was less reactive with $\mathrm{ClO}_{2}$, so a relatively large concentration of the divalent metal ion solution was required before it reduced $\mathrm{ClO}_{2}$ activity.

\section{RESULTS}

Activity of $\mathrm{ClO}_{2}$ against macro- and microconidia of $F$. oxysporum f. sp. narcissi. Several factors in experiments 1 and 2 had only values of 0 and $100 \%$ mortality with differences in dose of $2 \mathrm{mg} /$ liter but not consistently the same factors; therefore the SAS procedure of Proc Mixed was used initially to test significance of factors. Experiment $(P=0.5360)$ and spore type $(P$ $=0.8722)$ were not significantly different for $F$. oxysporum f. sp. narcissi, while all other factors were significant $(P<0.0001)$. Data for both experiments and macro- and microconidia were combined for the probit analysis. $\mathrm{LD}_{50}$ values were significantly higher with each incremental increase in concentration of divalent metal ion solution at $\mathrm{pH} 5$ and 8 (Table 1). $\mathrm{LD}_{50}$ values at $\mathrm{pH} 5$ were significantly lower than at $\mathrm{pH} 8$ when other factors were equal. At $\mathrm{pH} 8$, an increase from 0 to $100 \mathrm{mg}$ concentration of the nitrogen and hard water solution per 
liter resulted in lower $\mathrm{LD}_{50}$ values and indicated a negative interaction between the nitrogen and hard water solution and $\mathrm{ClO}_{2}$ (Table 1). Probit curves could not be calculated for the treatments of $\mathrm{pH} 5$ and 0 $\mathrm{mg}$ concentration of the nitrogen and hard water solution per liter, because no intermediate mortality values existed. For these treatments, mortality changed from 0 to $100 \%$ with an increase to the next $\mathrm{ClO}_{2}$ level, i.e., $2 \mathrm{mg} \mathrm{ClO}_{2}$ per liter. Results were not significantly different between day 1 and day 3 counts for spore germination. Plates with a very high percent spore germination on day 1 were difficult to count on day 3 . Because the spore germination counts for day 1 were more accurate than for day 3 , only data from day 1 were analyzed by Probit procedures.

Secondary lethal dose values that cause $50 \%$ mortality of spores at $\mathrm{pH} 8$ were significantly lower than at $\mathrm{pH} 5$ for both 0 and $100 \mathrm{mg}$ of the nitrogen and hard water solution per liter (Table 2). An increase from 0 to $100 \mathrm{mg}$ of the nitrogen and hard water solution per liter corresponded with a lower $2^{\circ} \mathrm{LD}_{50}$ at $\mathrm{pH} 5$ and a slightly higher $2^{\circ} \mathrm{LD}_{50}$ at $\mathrm{pH} 8$.

Activity of $\mathrm{ClO}_{2}$ against conidia of $\mathrm{T}$. basicola. Experiments 1 and 2 were significantly different. Similar trends in mortality were found with conidia of $T$. basicola as found with conidia of $F$. oxysporum f. sp. narcissi. Lethal dose values that cause $50 \%$ mortality of spores were significantly higher with each incremental increase in concentration of the divalent metal ion solution at pH 5 and 8 (Table 3). Lethal dose values that cause 50\% mortality of spores were significantly lower at $\mathrm{pH}$ 5 than at $\mathrm{pH} 8$ when other factors were equal, except at $0 \mathrm{mg} /$ liter of the nitrogen and hard solution and divalent metal ion solution. At $\mathrm{pH} 8$ and $\mathrm{pH} 5$ in experiment 1 , an increase from 0 to $100 \mathrm{mg}$ of the nitrogen and hard solution per liter resulted in lower $\mathrm{LD}_{50}$ values and indicated a negative interaction between the nitrogen and hard solution and $\mathrm{ClO}_{2}$ (Table 3). In the second experiment, $\mathrm{LD}_{50}$ values were not available at $\mathrm{pH} 5$ and $0 \mathrm{mg}$ of the nitrogen and hard solution per liter because no intermediate mortality values existed. Mortality changed from $0 \%$ at $1 \mathrm{mg} \mathrm{ClO}_{2}$ per liter to $100 \%$ at $3 \mathrm{mg} \mathrm{ClO}_{2}$ per liter at both 0 and $5 \mathrm{mg}$ of the divalent metal ion solution per liter. Data were not significantly different between day 1 and day 3 spore germination counts.

Trends in $\mathrm{LD}_{50}$ values were the same for conidia of $F$. oxysporum $\mathrm{f}$. sp. narcissi as they were with conidia of T. basicola. Secondary lethal dose values that cause $50 \%$ mortality of spores at $\mathrm{pH} 8$ were significantly lower than at $\mathrm{pH} 5$ for both 0 and $100 \mathrm{mg}$ of the nitrogen and hard water solution per liter (Table 4). An increase from 0 to $100 \mathrm{mg}$ of the nitrogen and hard water solution per liter corresponded with a lower $2^{\circ} \mathrm{LD}_{50}$ at $\mathrm{pH} 5$ in both experiments and a slightly higher $2^{\circ} \mathrm{LD}_{50}$ at $\mathrm{pH}$ 8 in experiment 1 only (Table 4 ).

Table 1. Probit prediction of chlorine dioxide $\left(\mathrm{ClO}_{2}\right)$ concentration (mg/liter) required to cause $50 \%$ mortality $\left(\mathrm{LD}_{50}\right)$ when $\mathrm{ClO}_{2}$ had reacted with the specified factors for $10 \mathrm{~min}$ before treatment of the macro- and microconidia of Fusarium oxysporum f. sp. narcissi for $30 \mathrm{~s}$

\begin{tabular}{|c|c|c|c|c|c|c|c|c|}
\hline \multicolumn{3}{|c|}{ Treatments } & \multirow[b]{2}{*}{$\mathbf{L D}_{50}{ }^{\mathrm{c}}$} & \multirow[b]{2}{*}{$\begin{array}{l}\text { 95\% confidence } \\
\text { limit }\end{array}$} & \multirow[b]{2}{*}{ Slope $^{d}$} & \multirow[b]{2}{*}{$\begin{array}{c}\text { Standard error } \\
\text { of the slope }\end{array}$} & \multirow[b]{2}{*}{$\mathbf{n}^{\mathrm{e}}$} & \multirow[b]{2}{*}{$L D_{90}{ }^{f}$} \\
\hline pH & $\begin{array}{l}\text { N-sHWa } \\
\text { (mg/liter) }\end{array}$ & $\begin{array}{c}\text { Cu-Fe-Mn-Zn } \\
\text { (mg//iter) }\end{array}$ & & & & & & \\
\hline 8 & 0 & 0 & 1.40 & $1.28-1.51$ & 1.69 & $0.0665 \mathrm{~d}$ & 24 & 2.15 \\
\hline 8 & 0 & 5 & 6.96 & $6.91-7.01$ & 1.24 & $0.0442 \mathrm{f}$ & 48 & 8.00 \\
\hline 5 & 100 & 0 & 0.50 & $0.47-0.53$ & 4.54 & $0.0381 \mathrm{~b}$ & 36 & 0.78 \\
\hline 5 & 100 & 3 & 1.99 & $1.93-2.05$ & 1.16 & $0.0312 \mathrm{f}$ & 48 & 3.09 \\
\hline 5 & 100 & 5 & 2.98 & $2.89-3.06$ & 0.72 & $0.0196 \mathrm{~g}$ & 60 & 4.75 \\
\hline 8 & 100 & 0 & 0.58 & $0.54-0.62$ & 5.06 & $0.2367 \mathrm{a}$ & 36 & 0.83 \\
\hline 8 & 100 & 1 & 1.89 & $1.79-2.00$ & 2.83 & $0.1606 \mathrm{c}$ & 24 & 2.34 \\
\hline 8 & 100 & 3 & 2.54 & $2.48-2.59$ & 1.40 & $0.0238 \mathrm{e}$ & 48 & 3.45 \\
\hline 8 & 100 & 5 & 4.27 & $4.19-4.35$ & 0.62 & $0.0149 \mathrm{~g}$ & 60 & 6.33 \\
\hline
\end{tabular}

a Concentration (mg/liter) of each: nitrogen from potassium nitrate, nitrogen from ammonium sulfate, and calcium carbonate equivalent (the unit for quantifying hard water).

${ }^{\mathrm{b}}$ Concentration (mg/liter) of each: copper, iron, manganese, and zinc.

${ }^{c}$ Lethal dose of $\mathrm{ClO}_{2}$ resulting in 50\% mortality of spores as predicted by Proc Probit (SAS Institute). Treatments with overlapping confidence limits at the $\mathrm{LD}_{50}$ are not significantly different. All probit curves had a $\chi^{2}$ probability of $<0.0001$.

${ }^{\mathrm{d}}$ Slope parameter and standard error of the slope were generated by probit analysis. Slopes were compared based on a $t$ distribution. Slopes with the same letter are not significantly different $(P=0.05)$.

e Number of samples $\left(\mathrm{ClO}_{2}\right.$ levels $\times$ replications) per calculation.

${ }^{\mathrm{f}} \mathrm{LD}_{90}$ values are listed as a reference to the $\mathrm{ClO}_{2}$ level likely to be used commercially to treat irrigation water.

Table 2. Probit prediction of concentration of a divalent metal ion solution required to interact negatively with the biocidal activity of $3 \mathrm{mg} \mathrm{ClO}_{2}$ per liter so the remaining $\mathrm{ClO}_{2}$ will cause a $50 \%$ mortality $\left(\mathrm{LD}_{50}\right)$ when the divalent metal ion solution, $\mathrm{ClO}_{2}$, and specified factors had reacted for 10 min before treatment of macro- and microconidia of Fusarium oxysporum f. sp. narcissi for $30 \mathrm{~s}$

\begin{tabular}{|c|c|c|c|c|c|c|c|c|}
\hline \multirow[b]{2}{*}{ pH } & \multicolumn{2}{|c|}{ Treatments } & \multirow[b]{2}{*}{$2^{\circ} \mathbf{L D}_{50}{ }^{b}$} & \multirow[b]{2}{*}{$\begin{array}{l}\text { 95\% confidence } \\
\text { limit }\end{array}$} & \multirow[b]{2}{*}{ Slope ${ }^{\mathrm{c}}$} & \multirow[b]{2}{*}{$\begin{array}{c}\text { Standard error } \\
\text { of the slope }\end{array}$} & \multirow[b]{2}{*}{$\mathbf{n}^{\mathbf{d}}$} & \multirow[b]{2}{*}{$\begin{array}{l}\text { Probability } \\
\text { chi-square }^{\mathrm{e}}\end{array}$} \\
\hline & $\begin{array}{c}\text { N-sHWa } \\
\text { (mg/liter) }\end{array}$ & $\begin{array}{c}\mathrm{ClO}_{2} \\
\text { (mg/liter) }\end{array}$ & & & & & & \\
\hline 5 & 0 & 3 & 12.95 & $9.12-53.14$ & -0.32 & $0.1364 \mathrm{a}$ & 48 & 0.0179 \\
\hline 5 & 100 & 3 & 5.22 & $4.76-6.00$ & -0.65 & $0.1183 \mathrm{ab}$ & 48 & $<0.0001$ \\
\hline 8 & 0 & 3 & 2.40 & $1.35-2.91$ & -1.65 & $0.5543 \mathrm{~b}$ & 48 & 0.0030 \\
\hline 8 & 100 & 3 & 3.81 & $3.32-4.32$ & -0.90 & $0.1782 \mathrm{~b}$ & 48 & $<0.0001$ \\
\hline
\end{tabular}

${ }^{a}$ Concentration (mg/liter) of each: nitrogen from potassium nitrate, nitrogen from ammonium sulfate, and calcium carbonate equivalent (the unit for quantifying hard water).

${ }^{b}$ A secondary lethal dose value $\left(2^{\circ} \mathrm{LD}\right)$ is different from a lethal dose value typically calculated with a probit analysis, because mortality was a measure of $50 \%$ mortality caused by $3 \mathrm{mg} \mathrm{ClO} 2$ per liter after it had reacted with the divalent metal ion solution and was not caused by the divalent metal ion solution. The $2^{\circ} \mathrm{LD}$ values were calculated only to compare treatments. Analysis was done using Proc Probit (SAS Institute). Treatments with overlapping confidence limits at the $\mathrm{LD}_{50}$ are not significantly different.

${ }^{\mathrm{c}}$ Slope parameter and standard error of the slope were generated by probit analysis. Slopes were compared based on a $t$ distribution. Slopes with the same letter are not significantly different $(P=0.05)$.

${ }^{\mathrm{d}}$ Number of samples $\left(\mathrm{ClO}_{2}\right.$ levels $\times$ replications) per calculation.

e Chi-square $\left(\chi^{2}\right)$ probability associated with a probit curve. 
Activity of $\mathrm{ClO}_{2}$ against aleuriospores of $\boldsymbol{T}$. basicola. Experiments 1 and 2 were significantly different. Similar trends in mortality were found with aleuriospores of T. basicola as were found with conidia of $T$. basicola and $F$. oxysporum f. sp. narcissi. The notable difference was that considerably higher levels of $\mathrm{ClO}_{2}$ were required to kill aleuriospores of T. basicola than the other fungal propagules tested in these experiments. Because preliminary experiments demonstrated the need for very high rates of $\mathrm{ClO}_{2}$ and a wide range in rates of $\mathrm{ClO}_{2}$, treatment selection was restricted even more than for the other propagules by combining the nitrogen and hard water solution (0 and $100 \mathrm{mg} / \mathrm{liter})$ and divalent metal ion solution $(0$ and 5 $\mathrm{mg} /$ liter) treatments. $\mathrm{LD}_{50}$ values were significantly higher for aleuriospores of $T$. basicola with an increase in concentration of the divalent metal ion solution and the nitrogen and hard water solution, except at $\mathrm{pH} 5$ in the second experiment (Table 5). All the $\mathrm{LD}_{50}$ values at $\mathrm{pH} 5$ were significantly lower than at $\mathrm{pH} 8$ when other factors were equal. Data were not signifi-

Table 3. Probit prediction of chlorine dioxide $\left(\mathrm{ClO}_{2}\right)$ concentration $\left(\mathrm{mg} /\right.$ /iter) required to cause $50 \%$ mortality $\left(\mathrm{LD}_{50}\right)$ when $\mathrm{ClO}_{2}$ had reacted with the specified factors for $10 \mathrm{~min}$ before treatment of conidia of Thielaviopsis basicola for $30 \mathrm{~s}$

\begin{tabular}{|c|c|c|c|c|c|c|c|c|c|}
\hline \multirow[b]{2}{*}{ Experiment } & \multicolumn{3}{|c|}{ Treatment factors } & \multirow[b]{2}{*}{$\mathbf{L D}_{50}{ }^{\mathrm{c}}$} & \multirow[b]{2}{*}{$\begin{array}{l}\text { 95\% confidence } \\
\text { limit }\end{array}$} & \multirow[b]{2}{*}{ Slope $^{\mathrm{d}}$} & \multirow[b]{2}{*}{$\begin{array}{c}\text { Standard error } \\
\text { of the slope }\end{array}$} & \multirow[b]{2}{*}{$\mathbf{n}^{\mathrm{e}}$} & \multirow[b]{2}{*}{$L D_{90}$} \\
\hline & pH & $\begin{array}{c}\text { N-sHWa } \\
\text { (mg/liter) }\end{array}$ & $\begin{array}{c}\text { Cu-Fe-Mn-Zn' } \\
\text { (mg/liter) }\end{array}$ & & & & & & \\
\hline \multirow[t]{12}{*}{1} & 5 & 0 & 0 & 1.29 & $1.10-1.50$ & 1.64 & $0.1186 \mathrm{~b}$ & 8 & 2.07 \\
\hline & 5 & 0 & 5 & 1.73 & $1.57-1.19$ & 0.73 & $0.0329 \mathrm{e}$ & 12 & 3.50 \\
\hline & 8 & 0 & 0 & 1.20 & $1.02-1.41$ & 1.58 & $0.1195 \mathrm{~b}$ & 8 & 2.01 \\
\hline & 8 & 0 & 5 & 11.80 & $10.43-13.95$ & 0.19 & $0.0233 \mathrm{c}$ & 12 & 18.40 \\
\hline & 5 & 100 & 0 & 0.53 & $0.47-0.57$ & 2.95 & $0.0381 \mathrm{a}$ & 12 & 0.96 \\
\hline & 5 & 100 & 1 & 1.01 & $0.91-1.10$ & 1.30 & $0.1259 \mathrm{c}$ & 8 & 2.05 \\
\hline & 5 & 100 & 3 & 1.89 & $1.77-2.00$ & 0.90 & $0.0424 \mathrm{~d}$ & 16 & 3.32 \\
\hline & 5 & 100 & 5 & 3.08 & $2.90-3.25$ & 0.47 & $0.0187 \mathrm{f}$ & 20 & 5.78 \\
\hline & 8 & 100 & 0 & 0.99 & $0.93-1.05$ & 1.89 & $0.1294 \mathrm{~b}$ & 12 & 1.67 \\
\hline & 8 & 100 & 1 & 1.99 & $1.90-2.08$ & 1.76 & $0.0813 \mathrm{~b}$ & 8 & 2.72 \\
\hline & 8 & 100 & 3 & 3.61 & $3.51-3.72$ & 0.98 & $0.0449 \mathrm{~d}$ & 16 & 4.92 \\
\hline & 8 & 100 & 5 & 5.56 & $5.40-5.72$ & 0.47 & $0.0184 \mathrm{f}$ & 20 & 8.31 \\
\hline \multirow[t]{9}{*}{2} & 8 & 0 & 0 & 1.40 & $1.22-1.58$ & 1.61 & $0.0094 \mathrm{~d}$ & 8 & 2.19 \\
\hline & 8 & 0 & 5 & 7.73 & $7.63-7.84$ & 1.08 & $0.0486 \mathrm{e}$ & 16 & 9.10 \\
\hline & 5 & 100 & 0 & 0.54 & $0.49-0.58$ & 3.13 & $0.0394 \mathrm{a}$ & 12 & 0.95 \\
\hline & 5 & 100 & 3 & 2.41 & $2.29-2.53$ & 0.82 & $0.0370 \mathrm{f}$ & 16 & 3.97 \\
\hline & 5 & 100 & 5 & 3.58 & $3.39-3.77$ & 0.38 & $0.0150 \mathrm{~h}$ & 20 & 6.91 \\
\hline & 8 & 100 & 0 & 1.01 & $0.95-1.08$ & 1.91 & $0.1344 \mathrm{c}$ & 12 & 1.68 \\
\hline & 8 & 100 & 1 & 1.96 & $1.85-2.07$ & 2.34 & $0.1350 \mathrm{~b}$ & 8 & 2.51 \\
\hline & 8 & 100 & 3 & 4.63 & $4.52-4.74$ & 0.89 & $0.0384 \mathrm{f}$ & 16 & 6.08 \\
\hline & 8 & 100 & 5 & 5.94 & $5.81-6.07$ & 0.65 & $0.0248 \mathrm{~g}$ & 20 & 7.92 \\
\hline
\end{tabular}

a Concentration (mg/liter) of each: nitrogen from potassium nitrate, nitrogen from ammonium sulfate, and calcium carbonate equivalent (the unit for quantifying hard water).

${ }^{\mathrm{b}}$ Concentration ( $\mathrm{mg} /$ liter) of each: copper, iron, manganese, and zinc.

${ }^{c}$ Lethal dose of $\mathrm{ClO}_{2}$ resulting in $50 \%$ mortality of spores as predicted by Proc Probit (SAS Institute). Treatments with overlapping confidence limits at the $\mathrm{LD}_{50}$ are not significantly different. All probit curves had a $\chi^{2}$ probability of $<0.0001$

${ }^{\mathrm{d}}$ Slope parameter and standard error of the slope were generated by probit analysis. Slopes were compared based on a $t$ distribution. Slopes with the same letter are not significantly different $(P=0.05)$

e Number of samples $\left(\mathrm{ClO}_{2}\right.$ levels $\times$ replications) per calculation.

${ }^{\mathrm{f}} \mathrm{LD}_{90}$ values are listed as a reference to the $\mathrm{ClO}_{2}$ level likely to be used commercially to treat irrigation water.

Table 4. Probit prediction of the concentration of a divalent metal ion solution required to interact negatively with the biocidal activity of $3 \mathrm{mg} \mathrm{ClO}_{2}$ per liter so the remaining $\mathrm{ClO}_{2}$ will cause a $50 \%$ mortality $\left(\mathrm{LD}_{50}\right)$ when the divalent metal ion solution, $\mathrm{ClO}_{2}$, and specified factors had reacted for 10 min before treatment of conidia of Thielaviopsis basicola for $30 \mathrm{~s}$

\begin{tabular}{|c|c|c|c|c|c|c|c|c|}
\hline \multirow[b]{2}{*}{ Experiment } & \multicolumn{3}{|c|}{ Treatment factors } & \multirow[b]{2}{*}{$2^{\circ} \mathrm{LD}_{50}{ }^{\mathrm{c}}$} & \multirow[b]{2}{*}{$\begin{array}{l}\text { 95\% confidence } \\
\text { limit }^{\mathrm{d}} \\
\end{array}$} & \multirow[b]{2}{*}{ Slope $^{\mathrm{e}}$} & \multirow[b]{2}{*}{$\begin{array}{c}\text { Standard error } \\
\text { of the slope }\end{array}$} & \multirow[b]{2}{*}{$\mathbf{n}^{\mathbf{f}}$} \\
\hline & pH & $\begin{array}{c}\text { N-sHWa } \\
\text { (mg/liter) }\end{array}$ & $\begin{array}{c}\mathrm{ClO}_{2}{ }^{\mathbf{b}} \\
\text { (mg/liter) }\end{array}$ & & & & & \\
\hline \multirow[t]{4}{*}{1} & 5 & 0 & 3 & 14.52 & $10.64-27.22$ & -0.20 & $0.0541 \mathrm{a}$ & 16 \\
\hline & 5 & 100 & 3 & 5.77 & $5.51-6.11$ & -0.58 & $0.0457 \mathrm{~b}$ & 16 \\
\hline & 8 & 0 & 3 & 2.18 & $2.09-2.28$ & -1.10 & $0.0429 \mathrm{c}$ & 16 \\
\hline & 8 & 100 & 3 & 2.49 & $2.39-2.60$ & -0.99 & $0.0405 \mathrm{c}$ & 16 \\
\hline \multirow[t]{4}{*}{2} & 5 & 0 & 3 & 20.25 & $12.3-89.56$ & -0.14 & $0.0576 \mathrm{a}$ & 16 \\
\hline & 5 & 100 & 3 & 5.60 & $5.31-5.96$ & -0.45 & $0.0306 \mathrm{~b}$ & 16 \\
\hline & 8 & 0 & 3 & 1.78 & $1.77-1.97$ & -1.57 & $0.0695 \mathrm{c}$ & 16 \\
\hline & 8 & 100 & 3 & 1.94 & $1.90-2.10$ & -1.93 & $0.0897 \mathrm{~d}$ & 16 \\
\hline
\end{tabular}

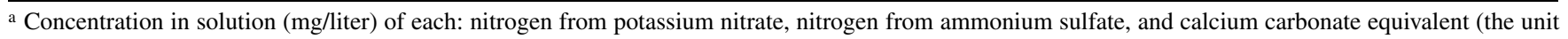
for quantifying hard water).

${ }^{\mathrm{b}}$ Concentration in solution (mg/liter) of chlorine dioxide.

${ }^{\mathrm{c}}$ A secondary lethal dose value $\left(2^{\circ} \mathrm{LD}\right)$ is different from a lethal dose value typically calculated with a probit analysis, because mortality was a measure of $50 \%$ mortality caused by $3 \mathrm{mg} \mathrm{ClO}$ per liter after it had reacted negatively with the divalent metal ion solution and was not caused by the divalent metal ion solution. The $2^{\circ} \mathrm{LD}$ values were calculated only to compare treatments.

${ }^{\mathrm{d}}$ Treatment differences were determined by overlapping confidence limits at the lethal dose resulting in $50 \%$ spore mortality $\left(\mathrm{LD}_{50}\right)$, a $t$ distribution of the slopes of the probit curves, and the corresponding standard error of the slopes. Analysis was done using Proc Probit (SAS Institute).

${ }^{\mathrm{e}}$ The slope parameter and standard error of the slope were generated by the probit analysis. Slopes were compared based on a $t$ distribution. Slopes with the same letter are not significantly different $(P=0.05)$.

${ }^{\mathrm{f}}$ Number of samples $\left(\mathrm{ClO}_{2}\right.$ levels $\times$ replications $)$ per calculation. 
cantly different between day 1 and day 3 spore germination counts.

\section{DISCUSSION}

Water properties, such as $\mathrm{pH}$ and water hardness, vary across regional and local sources of water, whether from above- or underground sources. In addition, the presence of nutrient leachates in surfacecaptured water can vary among sites and over time at individual sites. This research demonstrates the need to adjust the rate of $\mathrm{ClO}_{2}$ according to the demand requirements of the water solution as well as the pathogen and propagule type being targeted. Fungi and types of fungal propagule ranked in order of increasing levels of $\mathrm{ClO}_{2}$ necessary to achieve mortality were: $F$. oxysporum f. sp. narcissi (conidia) $\leq T$. basicola (conidia) $<<$ T. basicola (aleuriospores). The factors that affected activity of $\mathrm{ClO}_{2}$ in the order of decreasing reactivity were concentration of the divalent metal ion solution $>>\mathrm{pH}>$ concentration of the nitrogen and hard water solution. However, a 100-mg concentration of the nitrogen and hard water solution per liter interacted with $\mathrm{pH}$ to determine the need to increase and decrease $\mathrm{ClO}_{2}$ dose at $\mathrm{pH} 5$ and 8 , respectively, in order to maintain equal biocidal activity.

Chlorine dioxide rates needed to achieve $\mathrm{LD}_{50}$ values were similar for conidia of $F$. oxysporum f. sp. narcissi and T. basicola. Roberts and Reymond (24) noted mortality of Cryptosporiopsis perennans, Mucor piriformis, Penicillium expansum, and Botrytis cinerea spores reached 100.0, $100.0,99.2$, and $93.9 \%$, respectively, from $30 \mathrm{~s}$ exposure to $3 \mathrm{mg} \mathrm{ClO}$ per liter. Hong (13) observed $100 \%$ mortality of zoospores of Phytophthora nicotianae from 2 $\mathrm{mg}$ free $\mathrm{Cl}$ per liter (from $\mathrm{Cl}$ gas). It is likely that many fungal spores are killed by similar rates of chlorine in solution. Of concern were the high $\mathrm{LD}_{50}$ values for aleuriospores of $T$. basicola. While it was not the objective in this project to test $\mathrm{ClO}_{2}$ against all pathogens disseminated in water, this demonstrated the need to clarify rates of $\mathrm{ClO}_{2}$ needed for control of other thick-walled propagules, such as oospores and chlamydospores.

The largest demand on $\mathrm{ClO}_{2}$ activity came from the divalent metal ion solutions, which would most commonly occur in water as a micronutrient leachate in catchment ponds in nurseries and recirculated watering systems in greenhouses (2). Significant differences occurred between $\mathrm{LD}_{50}$ values of 0 and $1 \mathrm{mg}$ concentration of the divalent metal ion solution per liter, with that narrow range in concentration being representative of what could exist in recaptured water. The reactivity of $\mathrm{ClO}_{2}$ to divalent cations has been reported (7). In fact, $\mathrm{ClO}_{2}$ is used to reduce $\mathrm{Fe}$ and Mn levels in industrial water use (12).

Results from the use of $2^{\circ} \mathrm{LD}_{50}$ values concur with results from $\mathrm{LD}_{50}$ values but provide a broader characterization of the responses, which were consistent for conidia of $T$. basicola and $F$. oxysporum $\mathrm{f}$. sp. narcissi. Use of $2^{\circ} \mathrm{LD}_{50}$ values show that the divalent metal ion solution placed a higher demand on $\mathrm{ClO}_{2}$ at $\mathrm{pH} 8$ than at $\mathrm{pH} \mathrm{5}$, and the nitrogen and hard water solution in the presence of the divalent metal ion solution placed a higher demand on $\mathrm{ClO}_{2}$ at pH 5 but lowered demand on $\mathrm{ClO}_{2}$ at $\mathrm{pH}$ 8. Interactions between the nitrogen and hard water solution, the divalent metal ion solution, and $\mathrm{pH}$ likely involve several different chemical reactions. The chemical nature of these interactions is unclear from this research. It is unknown whether the responses from the nitrogen and hard water solution were due to N, sHW, or the combination. Since nitrogen has been proven by others not to place a demand on $\mathrm{ClO}_{2}$, sHW or the combination of $\mathrm{N}$ with sHW is more likely to be the important factor(s) in these interactions (8).

In nature, water hardness typically occurs at $\mathrm{pH}$ levels between 7 and 8 and is not associated with an acidic $\mathrm{pH}$. Regardless, sHW was tested at $\mathrm{pH} 5$ in this research. Differences in $\mathrm{ClO}_{2}$ activity due to the nitrogen and hard water solution did occur at $\mathrm{pH}$ 5. This reaction was not investigated further but shows that $\mathrm{Ca}$ and $\mathrm{Mg}$ can place a demand on $\mathrm{ClO}_{2}$ at an acidic $\mathrm{pH}$. The effect of the nitrogen and hard water solution on $\mathrm{ClO}_{2}$ activity at $5-\mathrm{mg}$ concentration of the divalent metal ion solution per liter was considerably lower in magnitude (difference of $1.35 \mathrm{mg} \mathrm{ClO}_{2}$ per liter) than that associated with just the divalent metal ion solution. Although the effects of $\mathrm{N}$ and sHW were confounded, the use of the nitrogen and hard water solution as a factor in these trials still provided rate predictions that included compensation for the presence of $\mathrm{Ca}$ and $\mathrm{Mg}$ in leachates at $\mathrm{pH} 5$.

Length of exposure to disinfestants and temperature, organic matter, soluble organic compounds, and turbidity of the water are other factors reported to influence efficacy of disinfectants, but they were not tested in these experiments $(10,12,19)$. Guidelines for commercial disinfestation of irrigation water could include rate adjustments due to shorter and longer exposure times, which would depend on flow rate and size of an irrigation system. The contribution of organic matter on the total demand load and the effect of temperature on volatility losses are factors that have been important in calculating rates of disinfectants (10). In human waste treatment systems, effluents placed a demand on $\mathrm{ClO}_{2}$ (7). However, suspended solids had little direct influence on $\mathrm{ClO}_{2}$, except when $\mathrm{ClO}_{2}$ could not reach microorganisms that colonized or became embedded in suspended solids. At low tem-

Table 5. Probit prediction of chlorine dioxide $\left(\mathrm{ClO}_{2}\right)$ concentration $(\mathrm{mg} / \mathrm{liter})$ required to cause $50 \%$ mortality $\left(\mathrm{LD}_{50}\right)$ when $\mathrm{ClO}_{2}$ had reacted with the specified factors for $10 \mathrm{~min}$ before treatment of aleuriospores of Thielaviopsis basicola for $30 \mathrm{~s}$

\begin{tabular}{|c|c|c|c|c|c|c|c|c|c|c|}
\hline \multirow[b]{2}{*}{ Experiment } & \multicolumn{3}{|c|}{ Treatment factors } & \multirow[b]{2}{*}{$\begin{array}{c}\text { Cu-Fe-Mn-Zn } \\
\text { (mg/liter) }\end{array}$} & \multirow[b]{2}{*}{$L_{50}{ }^{d}$} & \multirow[b]{2}{*}{$\begin{array}{l}\text { 95\% confidence } \\
\text { limit }\end{array}$} & \multirow[b]{2}{*}{ Slope ${ }^{\mathrm{e}}$} & \multirow[b]{2}{*}{$\begin{array}{c}\text { Standard error } \\
\text { of the slope }\end{array}$} & \multirow[b]{2}{*}{$\mathbf{n}^{\mathbf{f}}$} & \multirow[b]{2}{*}{$\mathbf{L D}_{90} \mathrm{~g}$} \\
\hline & pH & $\begin{array}{l}\text { Nitrogen }^{\mathrm{a}} \\
\text { (mg/liter) }\end{array}$ & $\begin{array}{c}\text { sHW }^{\mathrm{b}} \\
\text { (mg/liter) }\end{array}$ & & & & & & & \\
\hline \multirow[t]{4}{*}{1} & 5 & 0 & 0 & 0 & 17.68 & $12.05-21.93$ & 0.04 & $0.0041 \mathrm{a}$ & 24 & 47.63 \\
\hline & 5 & 100 & 150 & 5 & 33.04 & $30.05-34.28$ & 0.08 & $0.0045 \mathrm{~b}$ & 24 & 48.82 \\
\hline & 8 & 0 & 0 & 0 & 41.71 & $41.57-43.79$ & 0.10 & $0.0051 \mathrm{c}$ & 24 & 55.59 \\
\hline & 8 & 100 & 150 & 5 & 45.52 & $44.18-46.79$ & 0.08 & $0.0040 \mathrm{~b}$ & 24 & 61.55 \\
\hline \multirow[t]{4}{*}{2} & 5 & 0 & 0 & 0 & 16.09 & $13.01-18.78$ & 0.04 & $0.0025 \mathrm{a}$ & 24 & 46.90 \\
\hline & 5 & 100 & 150 & 5 & 15.02 & $12.39-17.37$ & 0.04 & $0.0020 \mathrm{a}$ & 24 & 47.08 \\
\hline & 8 & 0 & 0 & 0 & 25.14 & $22.66-27.39$ & 0.04 & $0.0020 \mathrm{a}$ & 24 & 57.98 \\
\hline & 8 & 100 & 150 & 5 & 32.67 & $30.58-34.51$ & 0.06 & $0.0035 \mathrm{~b}$ & 24 & 55.30 \\
\hline
\end{tabular}

${ }^{a}$ Concentration in solution (mg/liter) of nitrogen from potassium nitrate and from ammonium sulfate.

${ }^{\mathrm{b}}$ Concentration in solution ( $\mathrm{mg} /$ liter) of calcium carbonate equivalent (the unit for quantifying hard water).

${ }^{c}$ Concentration in solution $(\mathrm{mg} /$ liter) of each: copper, iron, manganese, and zinc.

${ }^{\mathrm{d}}$ Lethal dose of $\mathrm{ClO}_{2}$ resulting in 50\% mortality of spores as predicted by Proc Probit (SAS Institute). Treatments with overlapping confidence limits at the $\mathrm{LD}_{50}$ are not significantly different. The intercept was set at 0.35 for all probit curves except where $\mathrm{pH}=5$ and sHW $=0$, when it was set at 0.7 in experiment 1 and 0.5 in experiment 2. Analysis was done using Proc Probit (SAS Institute). All probit curves had a $\chi^{2}$ probability of $<0.0001$.

${ }^{\mathrm{e}}$ The slope parameter and standard error of the slope were generated by the probit analysis. Slopes were compared based on a $t$ distribution. Slopes with the same letter are not significantly different $(P=0.05)$.

${ }^{\mathrm{f}}$ Number of samples $\left(\mathrm{ClO}_{2}\right.$ levels $\times$ replications) per calculation.

${ }^{\mathrm{g}} \mathrm{LD}_{90}$ values are listed as a reference to the $\mathrm{ClO}_{2}$ level likely to be used commercially to treat irrigation water. 
peratures, disinfection kinetics are slower. At higher temperatures, $\mathrm{ClO}_{2}$ is less stable and decays more rapidly. With Giardia, 26 and $11 \mathrm{mg} \mathrm{ClO}_{2}$ per min per liter at 5 and $25^{\circ} \mathrm{C}$, respectively, were required to reduce the bacteria population below a $2.5 \log$ inactivation level (12).

Because disinfectants react quickly with ions in solution and decay due to environmental and physical factors, rates need to be high enough to compensate for the load demand so that remaining levels are sufficient to kill different fungal, bacterial, and viral genera and species. In contrast, higher doses increase costs, so knowing the lowest effective rate will help lower costs. The results from this research demonstrate, using a select number of factors, that rate adjustments are important with $\mathrm{ClO}_{2}$, and some types of fungal propagules are more tolerant of $\mathrm{ClO}_{2}$ than other pathogens. Additional research would further define these rates of $\mathrm{ClO}_{2}$ needed to manage plant pathogens in irrigation water. Rates of all disinfectants need to be selected by demand load considerations and the organisms being targeted (3).

\section{ACKNOWLEDGMENTS}

Portions of this research were funded by the Washington State Department of Agriculture and the USDA-ARS. Some equipment was loaned and chemicals provided by $\mathrm{CH}_{2} \mathrm{O}$ International, Inc., Olympia, WA. We thank Sadie Swallow, Donald Matheson, Taryn Urion, and Kim Luu for performing high-quality work throughout the project. Their contributions were very appreciated. Debbie Boykin (USDA Area Statistician) provided technical assistance in selecting experimental designs and analyses.

\section{LITERATURE CITED}

1. Amy, G., Bull, R., Craun, G. F., Craun, Gunther, F., Pegram, R. A., and Siddiqui, M. 2000. Disinfectants and disinfectant by-products. World Health Organization, Geneva, Finland.

2. Bilderback, T. E. 2002. Water management is key in reducing nutrient runoff from container nurseries. Horttechnology 12:541-544.

3. Block, S. S., ed. 1991. Disinfection, Steriliza- tion, and Preservation. Lea \& Febiger, Philidelphia, PA.

4. Bundgaard-Nielsen, J., and Nielsen, P. V. 1996. Fungicidal effect of 15 disinfectants against 25 fungal contaminants commonly found in bread and cheese manufacturing. J. Food Prot. 59:268-275.

5. Clesceri, L. S., Greenberg, A. E., and Eaton, A. D., ed. 1998. Water hardness. Pages 10-161 in: Standard Methods for the Examination of Water and Wastewater. 20th ed. Am. Public Health Assoc., Am. Water Works Assoc., and Water Environ. Fed. Washington, DC.

6. Copes, W. E., Chastagner, G. A., and Hummel, R. L. 2001. Influence of select inorganic ions and $\mathrm{pH}$ on fungicidal activity of chlorine dioxide in water. SNA Res. Conf. Proc. 46:284286.

7. Dernat, M., and Pouillot, M. 1992. Theoretical and practical approach to the disinfection of municipal waste water using chlorine dioxide. Water Sci. Technol. 25:145-154.

8. Dychdala, G. R. 1991. Chlorine and chlorine compounds. Pages 131-151 in: Disinfection, Sterilization, and Preservation. S. S. Block, ed. Lea \& Febiger, Philidelphia, PA.

9. Greenberg, A. E., Clesceri, L. S., Eaton, A. D., and Franson, M. A. H., ed. 1992. 4500-Cl B. Iodometric method I. Pages 4-38 to 4-39 in: Standard Methods for the Examination of Water and Wastewater. $18^{\text {th }}$ ed. Am. Public Health Assoc., Am. Water Works Assoc., and Water Environ. Fed., Washington, DC.

10. Haas, C. N. 1981. Rational approaches in the analysis of chemical disinfection kinetics. Pages 381-399 in: Chemistry in Water Reuse: Vol. I. W. J. Cooper, ed. Ann Arbor Sci., Ann Arbor, MI.

11. Helrich, K., ed. 1990. Synthetic hard water. Page 139 in: Official Methods of Analysis of the Assoc. of Official Analytical Chemists, Vol. I \& II, 15th ed. AOAC, Inc., Arlington, VA.

12. Hofmann, R., Andrews, S. C., and Ye, Q. 1999. Impact of Guiardia inactivation requirements on $\mathrm{ClO}_{2}$ by-products. Environ. Technol. 20:147-158.

13. Hong, C. X. 2001. Effect of chlorine concentration and contact time on zoospore survival of Phytophthora nicotianae. Southern Nursery Assoc. Res. Conf. 46:315-316.

14. Junli, H., Li, W., Nanqi, R., Fang, M., and Juli. 1997. Disinfection effect of chlorine dioxide on bacteria in water. Water Resources 31:607613.

15. Junli, H., Li, W., Nanqi, R., Li, L. X., Fun, S.
R., and Guanle, Y. 1997. Disinfection effect of chlorine dioxide on viruses, algae, and animal planktons in water. Water Resources 31:455460.

16. Kaczur, J. J., and Cawlfield, D. W., ed. 1993. Chlorous acid, chlorites, and chlorine dioxide. Pages 968-997 in: Kirk-Othmer Encycl. Chem. Technol., 4th ed., Vol. 5, John Wiley \& Sons, New York.

17. Masschelein, W. J., and Rice, R. G. 1979. Chlorine Dioxide, Chemistry and Environmental Impact of Oxychlorine Compounds. Ann Arbor Sci. Pub., Ann Arbor, MI.

18. Mebalds, M., Beardsell, D., van der Linden, A., and Bankier, M. 1996. Current research into water disinfestation for the nursery and cut flower industries. Combined Proc. Int. Plant Propag. Soc. 46:89-92.

19. Narkis, N., and Kott, Y. 1992. Comparison between chlorine dioxide and chlorine for use as a disinfectant of wastewater effluents. Water Sci. Technol. 26:1483-1492.

20. Neter, J., Kutner, M. H., Nachtsheim, C. J., and Wasserman, W. 1990. Applied Linear Regression Models. Irwin Book Team, Chicago, IL.

21. Noack, M. G., and Iacoviello, S. A. 1992. The chemistry of chlorine dioxide in industrial and wastewater treatment applications. Pages 1-19 in: The Chemistry of Chlorine Dioxide in Industrial and Wastewater Treatment Applications, 2nd Int. Sympos. Chem. Oxidation Tech. for the 90's. Vanderbilt University, Nashville, TN.

22. Olsen, N., Kleinkopf, G., Secor, G., Woodell, L., and Nolte, P. 2000. The Use of Chlorine Dioxide in Potato Storage. Univ. Idaho Ext. Bull. No. 825.

23. Price, D. 1977. Effects of temperature and inoculum concentration on infection of narcissus bulbs by Fusarium oxysporum f. sp. narcissi. Ann. Appl. Biol. 86:433-436.

24. Roberts, R. G., and Reymond, S. T. 1994. Chlorine dioxide for reduction of postharvest pathogen inoculum during handling of tree fruits. Appl. Environ. Microbiol. 60:28642868.

25. Robertson, J. L., and Preisler, H. K. 1992 Pesticide Bioassays with Arthropods. CRC Press, Boca Raton, FL.

26. Shere, L. 1948. Some comparisons of the disinfecting properties of hypochlorites and quaternary ammonium compounds. Milk Plant Monthly 37:66-69.

27. White, G. C. 1992. The Handbook of Chlorination. Van Nostrand Reinhold, New York. 